\title{
Prevention of Hypocritical Behavior and Its Perspective in Islamic Education
}

\author{
Syamsu Nahar \\ UIN SU Medan, Indonesia \\ e-mail:syamsunahar.edu@gmail.com
}

\begin{abstract}
Hypocritical behavior needs to be watched out for because it is symptomatic in the community, especially now with access to global relationships without any boundaries of place and time where it is associated through social media, people who are infected with this disease are very difficult to guess, can only be known with certain signs namely: lying, treasonous, broken promises, riya, like to slander and spread lies. The purpose of this study is to explore broadly regarding with detail concept of hypocricy from several vital point of views i.e. from Al-Qur'an, Hadith, and Islamic interpreters. Furthermore, it is also highly urgent to avoid ourselves and teenagers from being a hypocrite. Hence, recognizing signs and characteristics of hypocrites is also crucial in order for us to be more alert toward this issue. Many studies about hypocricy have been conducted by many researchers in various condition including education, politics, and so fort. In this study, hypocracy is also discussed from Islamic education perspective.
\end{abstract}

Keywords: characteristics of hypocrites, hypocritical behavior, perspective of Islamic education

\section{A. Introduction}

Alquran is the main reference for Muslims, in all activities, both related to Allah, which is implemented by ritual worship and it is well known as habl minallah, as well as relations between human and the environment, it is well known as habl minannas. The Alquran as a holy book which is absolutely believed by Muslim, has become a spring that never dries, even though it is always being drained. Because the value contained in it is extraordinarily unlimited, besides its universal value, it is always updated all the time.

One of many discussions in the Qur'an is regarding hypocrisy, a bad character that must be shunned by faithful people who believe in Allah and Prophet. Hypocritical behavior is hated 
by Allah and His Prophets, because this behavior is more dangerous than the infidel. The infidel is easily known by the identity and the behavior clearly that he is an infidel, but the hypocrite is not clear his identity, in the presence of believers (mu'min) he is as if someone who really believes in Allah and His Prophets, but behind a believer, is actually an enemy of a believer. The attitude of pretending to be faithful, his character who likes to denounce and reject the truth and these other negative characters are revealed in Al-Qur'an in various surah and verses. In general, Al-Qur'an cannot be understood properly and comprehensively if there is no knowledge related to Al-Qur'an, therefore it is necessary for interpretes or person who has the capability and scientific competence of Al-Qur'an to explain the purpose of the verses existed in Al-Qur'an. In this paper, the researcher described how exactly the hypocritical behavior in AlQur'an by analyzing the views of classical and modern interpreters, it is expected that this paper can reveal clearly and comprehensively the hypocritical behavior in the Quran.

Specifically about hypocricy, it is obvious that it has spread out in all aspects of life (Gastner et al., 2019). Moreover, there are many experts who define that hypocricy is a form of moral and behaviour deviations that can affect ourlives. Hypocrite is assumed to be someone whose action is inconsistent with his words (Alicke, Gordon, \& Rose, 2013; Aikin, 2008; Jordan et al., 2017; Kreps, Laurin, \& Merritt, 2017). In accordance with the previous researchers, Effrona et al. (2018) said that hypocrite is a person who has "word-deed misalignment". It means that there is also contradiction between what he is saying and doing. To sum up, hypocritical behavior is considered to be a negative behavior that lead to undeserve moral benefits such as being trusted (Effrona et al., 2018).

Other than that, identifying the concept of hypocricy in terms of meaning never seems to be enough and significant to discussed broadly. Particularly, research about hypocricy has been carried out by many researchers from various review i.e. general knowledge in life as well as specific aspects regarding with Islamic point of view. For example, these several researchers had researched about hypocricy from the view of Islamic aspects. It was Zamroni (2009) who had researched about hypocrisy according to the interpretation of al-Misbah who examines the hypocritical criteria in the interpretation of Al misbah by Quraisy Syihab. Then Putri (2018) discusses the same focus with different interpretation from Al Maraghi. Moreover, related research also done by Fajriyyah (2014) where in this case she investigated characteristics of hypocritical behavior according to Al-Baqarah verse 8-20.

Meanwhile, research out of Islamic point of view also has been studied such as a study from Isserow \& Klein (2017) where in their study, they explored how hypocricy issues have widespread all over years and drive significant effects to moral values in our lives. In career development, hypocricy is studied on how it can influence workers in administrative area in working place (Alawamleh, 2013). In this case, Alawamleh (2013) suggested that administrative hypocricy should be reduced by doing hard efforts. Then what actually result the hypocritical behavior? Naso (2007), Ortiz et al. (2016), and van Prooijen \& van Lange (2016) said that hypocricy is a consequence of dishonesty and unethical cultures so that people transfer those habits into their social lives.

Above studies regarding with hypocricy whether in common life situation or in Islamic point of view indicate that hypocricy is a matter of causing a corrupt personality toward nowadays youth characters as it is very essentials to pay attention to youth or students' behavior to build positive characters. Specifically, many studies also have been researched toward this focus i.e. Na'imah (2018) who discussed about the study of management of Islamic character 
education where it is the basis for developing empathy values for students. Therefore, examining personality, behavior, and spiritual values of students is a must for educators to save their characters (Harisa, 2019). In this case, as hypocricy has negatively influenced stduents' characters, they should be prevented from being a hypocrite by strengthening students' characters by relying on Al-Zanuji's character thingking (Hulawa, 2018; Abidin, 2017; Setiawan, 2014).

\section{B. The Concept of Hypocricy Based on Al-Qur'an and Hadith}

If it traces, linguistically, the word hypocrite comes from the words nafaqa (نَفَقَ), nifaqan ( (نِفَاق) which has the meaning to hold, take part in, talk about something in a religious view. His recognition from one person is different from the others. As for in the term of syara', a hypocrite is a person who outwardly has faith while in his heart renege, the other term is hypocritical or ambigudan is ambiguous.

Furthermore, if analyzed the type of hypocrite in Al-Qur'an consists of two parts, namely hypocrisy in the form of faith (nifaq I'tiqadi), and nifaq in the form of activities or behavior (nifaq 'amali).

\section{Nifaq, hypocrisy in the form of faith (Nifaq i'tiqadi)}

Hypocrisy in the form of faith or belief (nifaq i'tiqadi) is a big nifaq, that the person shows Islam, but he hides kufr. This type of hypocrite makes the person come out of religion and he is in the crust of hell. Allah gives the character of these types of hypocrites with various nature of wickedness, such as kufr, lack of faith, mockers and invective of religion and adherents and tendency for the enemies of Islam to join them in opposing Islam. In addition to the word nifaq, Al-Qur'an also uses the word $\left(k h a d a^{\prime} a\right)$ to describe people who bear that behavior. As well the Al-Qur'an refers to hypocrites having heart disease and even Allah adds to the disease. This is emphasized in surah Al-Baqarah verses 8-10:

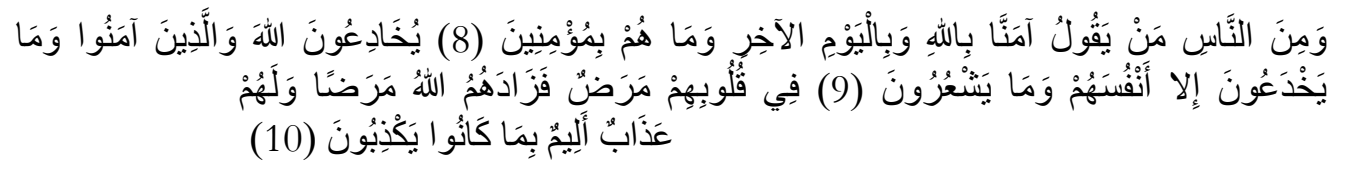

Among people there are those who say: "We believe Allah and the next day", even though they are not really believers. They want to deceive Allah and those who believe, in the case that they only deceive themselves while they are unconscious in their hearth there is a disease, then God added the disease; and for them a painful punishment, because they lie.

2. Nifaq in the form of activities or behavior (nifaq'amali)

Nifaq or hypocrisy in the form of activities or behavior (nifaq 'amali) is to do something that is the behavior of hypocrites, but the faith still exist. This type of hypocrisy does not make the person come out of religion, but it is an intermediary (washilab) to such. The person has both faith and nifaq. Then if the nifaq is more actions, then it can be the cause of falling into the real nifaq.

Al Qur'an mentions the word nifaq or hypocrites 37 times (Fuad, 1992), in various surah as mentioned on following table (Fuad, 1992). 


\begin{tabular}{|c|c|c|}
\hline O. & Hypocritical words & $\begin{array}{c}\text { Surah/surah number/verse (total } \\
\text { verses) }\end{array}$ \\
\hline & نَافْقَوْا & Ali Imran $/ 3 / 167=(\mathbf{1})$ \\
\hline & نَافَقْوْا & Al-Hasyr/59/11 = (1) \\
\hline & \multirow{7}{*}{ المُنَفِقِينَ } & $\begin{array}{l}\text { An-Nisa'/4/61, 88, 138, 140, 142, } 145 \\
=(6)\end{array}$ \\
\hline & & At-Taubah/9/67, 68, 73=(3) \\
\hline & & Al-Ankabut/29/11 = (1) \\
\hline & & Al-Ahzab/33/1, 24, 48, $73=(4)$ \\
\hline & & Al-Fath/48/6=(1) \\
\hline & & Al-Munafikun $/ 63: 1,7,8=(3)$ \\
\hline & & At-Tahrim/66/9 = (1) \\
\hline & \multirow{5}{*}{ الَمُنَاْفِقُونَ } & Al-Anfal/8/49 = (1) \\
\hline & & At-Taubah/9/64,67,101 = (3) \\
\hline & & $\mathrm{Al}-\mathrm{Ahzab} / 33 / 12,60=(2)$ \\
\hline & & Al-Hadid/57/13 = (1) \\
\hline & & Al-Munafikun/63:1 = (1) \\
\hline & الْنَفْاقِ & At-Taubah/9/101 = (1) \\
\hline & نِفَاقًا & At- $/$ Taubah/9/77, $97=(2)$ \\
\hline & \multirow{4}{*}{ المُنـاَفِقَاَت } & At-Taubah/9/67, $68=(2)$ \\
\hline & & Al-Ahzab/33/73 = (1) \\
\hline & & Al-Fath $/ 48 / 6=(\mathbf{1})$ \\
\hline & & Al-Hadid $/ 57 / 13=(\mathbf{1})$ \\
\hline & Tot & 12 surah and 37 verses \\
\hline
\end{tabular}

\section{The Criteria of Hypocrites in Hadith}

In Hadith basically there are some specialities or characteristics the behavior of hypocrites, as mentioned by Prophet Muhammad about three criteria of hypocrites as follow:

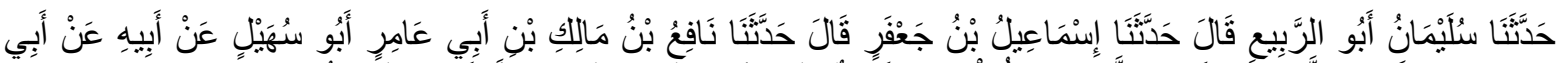

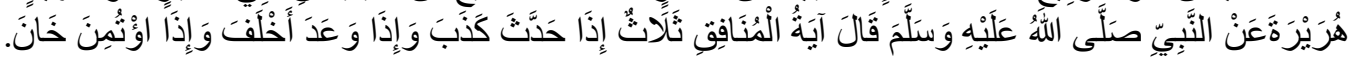

Has told us Sulaiman Abu ar-Rabi 'said, told us Isma'il bin Ja'far said, told us Nafi' bin Malik bin Abu 'Amir Abu Subail from his father from Abu Hurairah from the Prophet, He said: "There are three hypocritical signs; if speak he lies, if promise he reneges and if given the mandate, he will betray". (H.R. Al-Bukhari-32)

In another Hadith, the Prophet Muhammad also mention in detail regarding with four criteria of hypocrites:

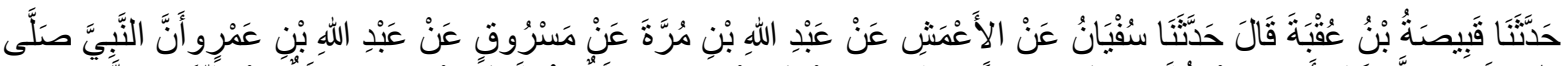

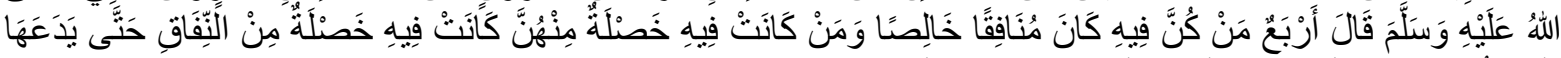

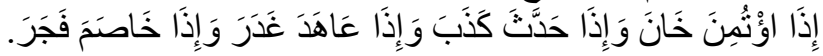

Has told us Qabishah bin 'Uqbah said, had told us Sufyan from Al-A'masy from Abdullab bin Murrah from Masruq from Abdullah bin' Amru that the Prophet said: "Four things if there is in a person he is real bypocrite 
, and whoever is in one of the four characteristics, then there is the nature of nifaq until he leaves it. That is, (1) if given the mandate he betrays, (2) if tells he lies, (3) if promises he deny and (4) if fight or feud is cheating or crossing the line ". (H.R. Al-Bukhari-33)

Moreover, another Hadith pointed out that one of criteria of hypocrites where they are in laziness of praying Isya and Subuh as mentioned as follow:

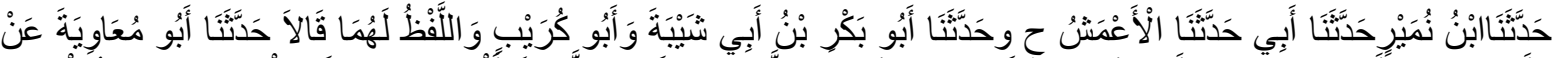

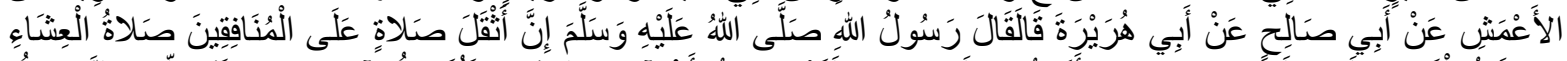

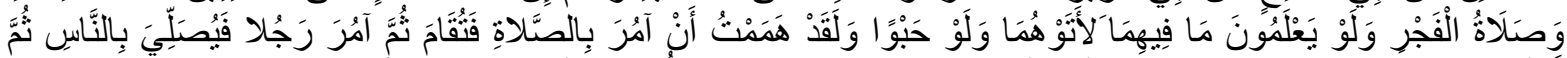

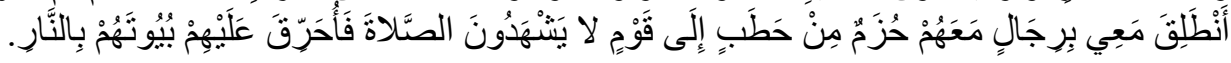

Having told us Ibn Numair had told us My father had told us Al-A'masy (and narrated from another way) had told us Abu Baker bin Abu Shafiib and Abu Kuraib while reciting the hadith from him, both said; he has told us Abu Mua wiyah from Al-A'masy from Abu Salih from Abu Hurairah he said; Prophet said: "Prayer that is felt heavy for hypocrites is Isya and Subuh prayer, if they know the virtues, surely they will come even if by crawling. Really, I wish to order someone so that prayer is established, then I tell someone else and he leads the people Then I and some people brought firewood to meet a people who did not attend the prayer, then I burned their house”. (H.R.Muslim-1041)

The next Hadith of Prophet Muhammad explained that there is a threat as deed of the prophet, if a hypocrite dies, the prophet will not prayed the coprse because it is prohibition of Allah, this is the punishment of Allah, which gives an indicator of very bad behavior of a hypocrite, even the hypocrite has death the Prophet doesn't have permisson to pray for him, considering the following hadits.

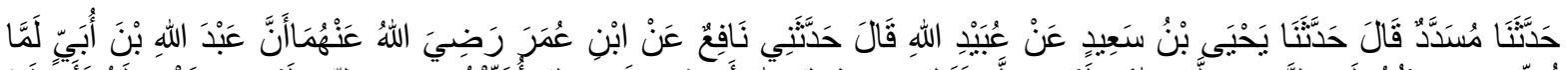

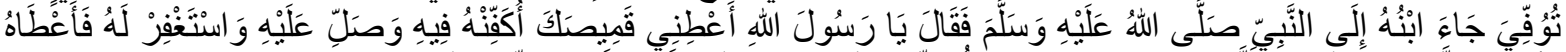

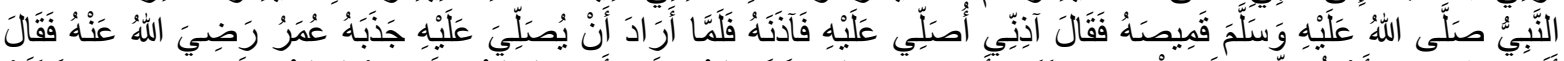

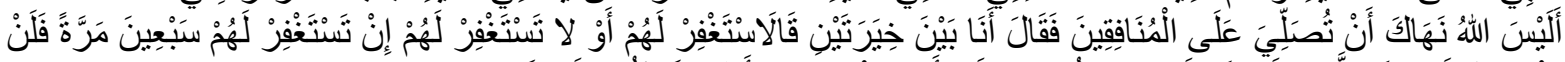

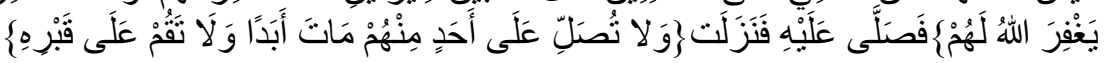

Has told us Musaddad said, had told us Yabya bin Sa'id from 'Ubaidullab said, had told me Nafi' from Ibn'Umar ra. That when 'Abdullah bin Ubay died, his son came to the Prophet then said: "O Rasulullah saw.:"Give me your clothes for to understand my father and pray for him and ask for forgiveness for him." So, the Prophet gave him his clothes and said: "allow me to pray for him." When the prophet wants to pray, 'Umar bin Al-Khaththab r.a suddenly came and said to the Prophet: "Did not Allah forbid you to pray a bypocrites?" So, He said: "I am in two choices from the word of Allab (Q.S. At-Taubah verse 80, which means):" You ask forgiveness for them or you do not ask forgiveness for them (just the same for them). Even if you ask forgiveness for them seventy times, Allah will never forgive them. "So, the Prophet does the praying. Then a verse came down: (Q.S Surab At-Taubah verse 84 which means) "Do not pray anyone who has died from them forever, and do not stand on a hypocrite's grave” (H.R Al-Bukhari-1190).

\section{Hypocricy Based on Islamic Interpreters}

Concerning with the concept of hypocricy, it is divided into two kinds of interpreters i.e. classical and modern intrepreters. Specifically, classical interpreters are represented by Muhammad Rasyid Ridha, Al-Qurthubi, At-Tabari, Az-Zamakhsyari, Ibn Kasir, and Jalaluddin 
As-Sayuthi. Meanwhile, the modern interpreters are represented by Muhammad Husein Thabathaba'i, Muhammad Quraish Shihab and Hamka. Before expressing their views on the hypocritical verses in the quran, the following are explanatiosn of the interpreters, both classical and modern about hypocritical terminology.

According to Muhammad Rasyid Ridha (w.1345 H), he stated that hypocrites are people who do not want to use intellect to accept Islam, even though it can understand and know good and bad, but they have followed the taghut (Ridha, 1999). In addition, Muhammad Husein Thabathaba'i explained that hypocrites are the people who displaying acts of faith but harboring disbelief (Thabathabai, 1995). Furthermore, Al-Qurthubi (2002), explained that hypocrites are Muslim but still infidel, because they do not heve faith.

Meanwhile, according to Al-Asfahani (2008) as one of modern interpreters explain about hypocrites that nifaq is defined as, "entering into religion (syara') 'from one door and coming out of it through another door". This interpretation is based on Q.S.at-Taubah/9: 67. In addition, in the view of another modern interpreter, M. Quraish Shihab, the word hypocrite is taken from the word nafiqa, which means the mouse holes, a kind of tunnel that has two holes where it comes in and out. If being pursued here it comes out there, and vice versa. Shihab continues, as the character of hyocrites, he belongs to the group of believers by their confession of "I believe in Allah", and also belongs to the group of people who are kufr with the words "I am like you (Shihab, 2006).

Based on the description above, it can be said that nifaq is a heart disease or psyche that blossoms in the hearts of people who are not strong in his faith yet. Hypocrites are people who have a dual role in religious life. In other words, hypocrites are the people have two-faced, namely by displaying good intentions or faith when dealing with Muslims, but keep the nature of revenge and envy in his heart. According to some interpreters, the indication of nifaq have begun to appear when the Islamic dakwah in Makkah. The phenomenon of apostasy in their view is the beginning of hypocrisy. However, when Islam does not exist in Makkah, hypocrisy has not been felt by Muslim yet.

After the Prophet migrated to Madinah, nifaq's disease played its role by interfering and obstructing da'wah of Islam. Actually, the factors that cause hypocrisy - besides internal factors (weak faith) — are due to social jealousy. As the historian informed that before the arrival of Islam to Madina, the reins of leadership were handed over by two Arab tribes of Medina, Aus and Khazraj to Abdullah bin Ubay. He is the most influential and respected person among them. However, after the prophet and the Muslim arrived in Madina by bringing Islamic teaching with the egalitarian and humanist, the attention of the Arabian Madinah who originally directed at Abdullah bin Ubay moved to the Prophet. This was ultimately triggered the anger of Abdullah bin Ubay, so he decided to convert to Islam with the intention to destroy it from inside. Responding to the increasing danger of the hypocrites for the Muslims, Allah then explained their characteristics and characteristics features in various surah, there was even one surab that was taken from this group, namely al-Munafiqun. Hopefully what is served in this paper gives a clear description of the hypocrites and their influence in the da'wah of Islam.

\section{E. Hypocritical Behavior in Islamic Education Perspective}

If traced in the history of Islam, the appearance of hypocrites in Islam are just happened, in reality and in large numbers, it can be said in Madinah period. Even though in Makkah 
period, before the Prophet's migration or what so called by hijrah, there were already symptoms of hypocrisy, but there were no strong factors to encourage hypocrites in large numbers.

Related to this matter, Hamka (1982) explains that there are two groups of hypocrites in Madinah. First, hypocrites from among the Jews who felt increasingly pressured, even though before the arrival of Prophet Muhammad and Muslims to Madinah they were the householder in Madinah. This is because their lives are more prosperous compared to the original Arabian. However, after the arrival of Prophet Muhammad, they were increasingly pushed to the suburb. While the second hypocrite group is the Arabian of Madinah, led by Abdullah bin Ubay.

Furthermore, in Al-Qur'an, in various surah and verses, it is already explained that hypocrisy (nifaq) is one of mental illnesses or abnormalities in human. It is confimed that the weakness of faith in someone will control his behavior. This is where the need for spiritual education or what so called by tarbiyah an-nafs such as hasad, greedy, rapacious, revenge, arrogant, arrogant, haughty, and so fort. The disease resides in the hearts of hypocrites has an impact on their lives by always making damage on this earth. This is reflected in verses 11-12 of surah AlBaqarah verses $11-12$ as follow:

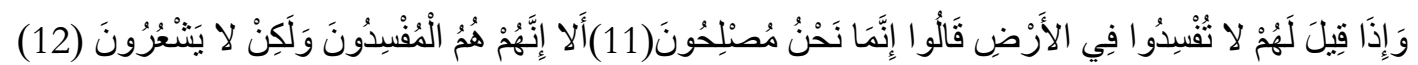
And when it is said to them: "Do not make damage in the universe", they answer: "We indeed make repairs." Remember, in fact they are the people who make damage, but they are not aware.

From above surah, it can be learned that hypocrites really do the damage. Therefore, $\mathrm{M}$. Quraish Shihab stated that the damage they did was reflected for them, who were reluctant to seek treatment so that the disease they suffered was getting worse. Furthermore, the destruction will certainly spread to their families and children, because the badness is transmitted through the exemplification of bad character (Shihab, 2006). Not only that, the destruction caused by hypocrisy also has an impact on social life by preventing others from virtue such as by spreading negative issues, instilling hatred and breakdown the society (Shihab, 2006).

Among the interpreters, especially the classical one, Al-Bayanuni (1970) classified hypocrisy as the worst type of Kufr (aqbah 'anwa' al-kufr). It is because the hypocrites have terrible disease in their heart e.g. betrayal, lying, deception, and disbelief. It was stated by Muhammad Rasyid Ridha that the spirit of a hypocrite is the most evil spirit, his soul is the worst soul, and his mind is the most heinous-mind. Because of that, Allah will place them in the worst place on the day after, which is the lowest level of hell (Ridha, 1999), as clearly stated in surab An-Nisa verse 145;

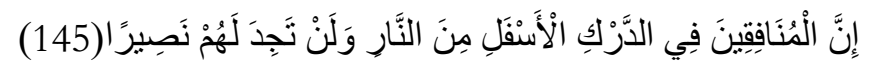

Surely the bypocrites placed at the lowest level of hell. And you will never get a helper for them.

The verse above provides a lesson for Muslim to not fall into hypocritical behavior because the threat of Allah towards the hypocrites is so powerful and dreadful that is placed in the lowest hell. Therefore, this kind of behavior should be shunned by every Muslim.

\section{F. Signs of Hypocritical Behaviour}

Hypocritical behavior is despicable behavior that needs to be spurned because someone who is infected with this disease can camouflage and has a potential to damage social order. This behavior has been rampant in the community, especially at the moment with access to 
global relationships such as social media interaction, people who are infected with this disease are very difficult to predict and can only be known with certain signs. The signs or indicators include:

\section{Lie}

Hypocrites have the characteristics of lying, this can be seen from Al-Qur'an surab AlMunafiqun verses 1-2;

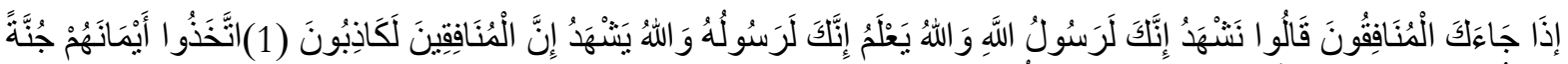

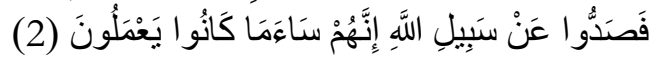

When hypocrites come to you, they say: "We admited that you truly are the Messenger of Allah." And Allah knows that truly you are His Messenger; and Allab knows that the bypocrites are really liars. They make their vow as a shield then they block humans from the path of Allah. Surely it is very bad what they have done.

Ibn Kasir (2004) elaborated above verse, that if hypocrites come to you, they say with their mouths about things that are contrary to what is in their hearts "We admited that you truly are the Messenger of Allah "And Allah knows that you really are His Messenger; and Allah witnesses, that is knowing that the hypocrites are really liars, what is in their hearts is different from what they say.

In the context of education area, many students do not realize that cheating when doing exam and copying another person's work are considered to be an academic lying behavior. Hence, it is important to notice to students that having a high grade is not the purpose of life because their characters are more determining their success in life.

\section{Two-faced Trait}

Another characteristic of a hypocrite is two-faced which means that hypocrites are very difficult to develop true friendships with other people because of their inconsistency. Instead they are very easy to trait and evenIn addition, they are easy to sacrifice their own friends in order to achieve their purposes which can prosper them. It is what exactly mentioned in AlQur'an surah An-Nisa verses 139-141 as follows:

"That is those who take unbelievers to help friends by leaving the believers. Are they looking for strength on the side of the infidel? Surely all the power belongs to Allah. And indeed Allah has revealed to you in the Qur'an when you hear the verses of Allah being denied and mocked by unbelievers, then do not sit down with them, so they talk another conversation. Because truly if you do it, surely you are same to them. Truly Allah will gather all the bypocrites and disbelievers in Hell, those who are waiting for events that will happen to you $O$ believers. So if victory for you by Allah, they say: "Didn't we join the battle with you? "And if the disbelievers have good luck in the victory they say: "Didn't we also win you, and defend you from the believers?" Then Allah will make a decision among you on the Judgment Day and Allah will never give way to the disbelievers to destroy those who believe".

Based on the verses above, Ibn Kasir (2004) explained that hypocrites in Madinah had made a tacit alliance with infidels or polytheists to destroy Muslim. At the time of the war between the Muslim and the polytheists and victory on the Muslims, the hypocrites immediately came forward to raise their hands as who was very instrumental in helping Muslim to win the 
war. However, when the Muslim lost and the infidels won, the hypocrites also appeared to the infidels, clapping their chests as the heroes who determine the victory over the Muslim. In this case, the betrayal behavior of the mandate given is a big mistake.

\section{Broke Promise}

In Al-Qur'an surah at-Taubah verses 75-78, it is explained the hypocritical characteristics that easily break promises that have been agreed, the translation of the verses are as follows: And among them there is who have vowed to Allah: "Verily, if God gives a part of His gifts to us, we will surely give alms and surely we are among the pious. So after God gave them a part of His gift, they are stingy with that gift, and turn away, and they are indeed those who always turn their backs the truth, so Allah causes bypocrisy in their hearts until they meet God, because they have denied Allah, what they have vowed to Allah and also because they always lie, do they not know that Allah knows their secrets and whispers, and that Allab knows all unseen?

Based on sabab an-nuzul, above verses are actually related to a person named Sala'bah bin Hatib Al-Ansari in the era of Prophet Muhammad (At Thobari, 2000; As-Suyuthi, 1994). In general, these verses are addressed to all hypocrites as a reproach to them which easily broke promises. In this case, they cannot responsible for mandate and any responsibility.

\section{Riya'}

Riya' is another behavior of hypocrites where they want pople see their good deed such as charities, etc. It is based on Al-Qur'an verse 142 as stated as follow:

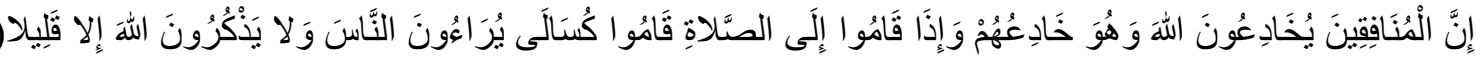

Surely the hypocrites deceive Allah, and Allab will replay their deception. And when they stand for praying, they stand lazily. They have riya (in their prayer) of humans. And they do not remember Allab except very little.

As-Suyuthi (1994) explains the verse above, indeed, the hypocrites deceive Allah by showing things that are contrary to disbelief that they hide it to avoid the worldly laws which related it and Allah deceives them to replay their deception by telling what they hide to His prophet until their secrets were opened in this world while in the hearafter they will get suffering. And if they stand to pray with the believers they stand lazily and they are riya for human with the prayer and not do zikir (remembrance) to Allah by means they do not pray except for a short time because of riya.

Moreover, Az-Zamakhsyari (1966), in his interpretation, Al-Kasysyaf 'an Haqa'iq AtTanzil wa' Uyun Al-Aqawil fi Wujuh At-Ta'wil, argued that hypocrites only remember Allah only a little amount of time. Most of their time they spend for world business. In addition, AzZamakhsyari (1966) argued that the word qalila at the end of the verse above can be interpreted as "adam" which means "no". The sentence implies that hypocrites do not remember Allah in their prayers or do not glorify to Allah in their lives.

Above kind of behavior describes hypocrites who never ready to achieve goodness that are nobel with eternal value. This attitude also describes a person who does not want to take difficulties, does not want to work hard, and not willing to sacrifice even a little to achieve positive aspects in life. Other than that, a person like this intends to make religion as median to get the world enjoyment. In other words, all his actions are always based on worldly profits. 
Therefore, hypocrites clearly cannot be expected become social, who is willing to reach out to help others except with certain rewards. Hypocrites are asocial people. People like this has littlefriends, especially true friends, of course people will stay away of them when they find out their hypocrisy behavior and attitudes.

\section{Slander and Share Hoax}

The other characteristics of hypocrites are slander and share hoax with the aimed is to vilify Muslim. In the era of Prophet Muhammad, hypocrites in Madinah, under the leadership of 'Abdallah bin Ubay, often used slander as a weapon to destabilize Muslim. For example, there was a hypocrite who slander 'Aisyah by saying that 'Aisyah did immoral deed with one of sahabat, Safwan bin Al-Mu'attal. This slander shocking the Prophet Muhammad until special surah of An-Nur verses 11-20 were descended to clean up 'Aisyah from the accusation.

Hypocritical criteria that have been described above showed that hypocritical behavior must be shunned by Muslim. Both classical and modern interpreters do agree that hypocrisy is a very bad behavior for humanity, it destroys social order, true friendship, brotherhood, and even always shared hostility to anyone who obstructs his interests. The importance of hypocrites are worldly benefits, they are not interested slightest in preparing their provisions in hearafter which more peaceful and eternal because of their weakness of belief and faith.

\section{G. Important Aspects in Avoiding Hypocritical Behaviour}

An educator is a person who is responsible for students' moral and it becomes an obligation for him to make efforts to educate students to avoid hypocritical behavior. here In this case, Abidin (2019) pointed out that there are several aspects that can directly or indirectly prevent students from hypocritical behavior as follows:

\section{Aspect of Faith}

Educated faith in of students is on obligation of educators. Educate a sense of faith must be carried out in right ways and in accordance with righteous faith so that they can have strong faith grown in their soul. Early grown faith will drive kids to have intended behavior by being a raw model for them and bring them good habits everyday. At the end, they are expected to develop themselves soon when they grew up in accordance with Islamic values. Specifically, kinds of efforts that educators can do is introducing to students the Islamic symbols, worship procedures, teaching them six pillars in Islam, obligation to do five times prayers everyday, and so fort. Those positive religious activities will create good habits and build virtuous characters until they are mature.

\section{Aspect of Morality}

Early morality needs to be instilled through parents' education. In this case, the role of a family is the most substantial case for the growth and development of students' behavior. Good morality will create noble behavior and vice versa, when students have sort of shameless morality so that it will lead them to corrupt behavior. Related to this point, Khazaei (2019) explained that building morality is one of main focuses in Islamic education. Is is intended to promoting moral virtues and good deeds based on Islamic rules. 


\section{Aspect of Islamic Syari'ah Implementation}

Syariah is the second foundation in for muslim after faith, so it can also be said that syariah is a realization of faith which is essentially included in Islamic provisions. While amaliyah syari'ah is indicated by worship practiced evryday according to all endowmentin Islam. In this case, to apply syariah in Islam is not easy. Therefore, students need to be taught starting from early age about Islamic obligations. It becomes very important in our lives because syariah enforcement will imply to the application of doing kindness and avoid harmful actions or what so called by amar ma'ruf nabi munkar.

\section{H. Conclusion}

It is obvious that taking care of students' characters is a must both for parents and teachers. It is because our students' characters are gained from sort of behavior they have and do everyday. Hence, the students must be kept away from depraved deeds such as hypocricy because it is very dangerous not only themselves, but also for other people. Moreover, from the views of Al-Qur'an and Hadith, it is already explained very clearly about the consequences of being hypocrites that they will be put in the lowest level of hell.

Students from early age should be taught based on Islamic regulation i.e. for not doing sort of characteristics of hypocites e.g. lying, betraying, breaking promises, riya', slander, and spread lies. People with hypocites' traits are very dangerous because they are very difficult to predict and recognize. They also do sort of worship activities as other Muslim, but they are away from rememberence of Allah in their heart. Therefore, teaching our students about faith, morality, as well as Islamic syariah will lead them to evade them from bad characteristics including hypocricy.

\section{BIBLIOGRAPHY}

Abidin, A. A. (2017). Pembentukan Karakter Siswa Melalui Internalisasi Nilai-Nilai Anti Korupsi. Jalie: Juornal of Aplied and Linguistics and Islamic Education, 1(2).

Abidin, A. A. (2019). Ilmu Pendidikan Islam. Malang: Humanis.

Aikin, S. F. (2008). Tu Quoque Arguments and the Significance of Hypocrisy. Informal Logic, 28(2), 155-169.

Al-Asfahani, A.-R. (2008). Mu'jam Mufrodat al-Fadhil al-Qur'an. Lebanon: Dar Al-Kotob Alilmiyah.

Al-Bayanuni, A. I. al-D. (1970). Al-Kufr Wa Al-Mukkeairat. Hal: Maktabah Al-Huda.

Al-Qurthubi, A. A. M. ibn A. ibn A. (2002). Al Jami' Li Abkamil Qur'an. Kairo: Darul Hadits.

Al Qur'an. (1989). Al Qur'an dan Terjemabnya. Semarang: Al-Awwah.

Alawamleh, H. S. (2013). The Impact of the Administrative Hypocrisy on the Career Path from the Perspective of the Administrative Staff at Al- Balqa' Applied University. International Journal of Business and Social Science, 4(11), 120-132.

Alicke, M., Gordon, E., \& Rose, D. (2013). Hypocrisy: What Counts? Philosophical Psychology, 26(5), 673-701.

As-Suyuthi, J. (1994). Al-Durr Al-Mantsur fi Al-Tafsir Al-Ma'tsur. Beirut: Darr Al-Fikr.

At Thobari, A. J. M. B. J. B. Y. B. K. (2000). Jami'ul Bayan Fi Ta'wilil Qur'an. Mesir: Muassasatur Risalah.

Az-Zamakhsyari, A. A.-Q. M. I. 'Umar. (1966). Al-Kasysyaf 'an Haqa'iq at-Tañil wa 'Uyun AlAqawil fi Wujuh At-Ta'wil (Jilid 1). Mesir: Mustafa Al-Babi Al-Halabi. 
Effrona, D. A., O’Connorb, K., Leroyc, H., \& Lucas, B. J. (2018). From Inconsistency to Hypocrisy: When Does "Saying One thing but Doing Another" Invite Condemnation? Research in Organizational Behavior, Article in.

Fajriyyah, N. (2014). Karakter Munafik Sebagai Gangguan Kepribadian Dalam Surat Al-Baqarah Ayat 8-20 : Kajian Tafsir Surat Al-Baqarah 8-20. UIN Sunan Ampel Surabaya.

Fuad, M. (1992). 'Ab Al-Baqiy, Al-Mu'jam Al-Mufahras Li-Alfaz. Al-Qur'an Al-Karim. Beirut: Dar Al-Ma'rifah.

Gastner, M. T., Taka', K., Gulya, M., Szvetelszky, Z., \& Oborny, B. (2019). The Impact of Hypocrisy on Opinion Formation: A Dynamic Model. PLoS ONE, 14(6), 1-21.

Hamka, H. (1982). Tafsir Al-Azhar. Jakarta: Panji Masyarakat.

Harisa, A. (2019). The Influence Of Counseling Guidance And Spiritual Intelligence In Developing Students' Islamic Personality. Jurnal Pendidikan Islam, 5(1), 75-86.

Hulawa, D. E. (2018). Al-Zarnuji's Character Concept In Strengthening Character Education In Indonesia. Jurnal Pendidikan Islam, 4(2), 25-40.

Ibn Kasir, A. al-F. I. (2004). Tafsir Al-Qur'an Al-Azhim. Ar-Riyadh: Dar As-Salam Li An-Nasyr Wa At-tauzi.

Isserow, J., \& Klein, C. (2017). Hypocricy and Moral Authority. Journal of Ethics and Social Philosophy, 12(2), 191-222.

Jordan, J. J., Sommers, R., Bloom, P., \& Rand, D. G. (2017). Why Do We Hate Hypocrites? Evidence for a Theory of False Signaling. Psychological Science, 28, 1-13.

Khazaei, Z. (2019). The Role of Religion in Shaping Moral Character: an Islamic Perspective. JPTR, 79, 1-10.

Kreps, T. A., Laurin, K., \& Merritt, A. C. (2017). Hypocritical Flip-Flop, or Courageous Evolution? When Leaders Change Their Moral Minds. Journal of Personality and Social Psychology, 113(5), 730-752.

Na'imah, N. (2018). Islamic Character Education Management in Developing the Empathy Values for Students Islamic of State University of Sunan Kalijaga Yogyakarta. DINAMIKA ILMU, 18(2).

Naso, R. C. (2007). Hypocrisy Unmasked - Dissociation, Shame, and the Ethics of Inauthenticity. Development.

Ortiz, M. J., Oraker, J. R., Malmstrom, F. V., \& MacGregor, J. (2016). Dishonesty and Hypocrisy in Service Academy Honor Systems. Research in Higher Education Journal, 31, 1-22.

Putri, A. K. (2018). Karakteristik Munafik dalam Alquran: Tafsir Al-Maraghi. UIN Sunan Gunung Djati Bandung.

Ridha, M. R. (1999). Tafsir Al Qur'an Al Hakim. Beirut: Darul Kutub Al Ilmiyah.

Setiawan, A. (2014). Prinsip Pendidikan Karakter dalam Islam: Studi Komparasi Pemikiran AlGhazali dan Burhanuddin Al-Zarnuji. DINAMIKA ILMU, 14(1), 1-12.

Shihab, M. Q. (2006). Tafsir Al-Mishbah (Vol. 2). Jakarta: Lentera Hati.

Thabathabai, M. H. (1995). Al-Mizan Tafsir Al-Qur'an. Beirut: Mu'assasah Al-A'lami li AlMatbu'at.

van Prooijen, J. W., \& van Lange, P. A. M. (2016). Cheating, corruption, and concealment: The roots of dishonesty. In Cheating, Corruption, and Concealment: The Roots of Dishonesty. https://doi.org/10.1017/CBO9781316225608

Zamroni, A. (2009). Munafik Menurut Tafsir Al-Misbah. IAIN Sunan Ampel Surabaya. 